\title{
The Impact of Corporate Governance on Earnings Management: The Case Of Pakistan Textile Industry
}

\author{
Shahzad Ahmad \\ Department of Management Sciences, \\ City University of Science \& IT Peshawar \\ shahzadahmad1244@hotmail.com \\ Asad Sarfaraz Khan \\ PhD scholar Institute of Busienss Studies and Leadership \\ Abdul Wali Khan University Mardan \\ asad_as2002@hotmail.com \\ Dr. Muhammad Zahid \\ Department of Management Sciences, \\ City University of Science \& IT Peshawar \\ mianmz11@gmail.com
}

\begin{abstract}
Due to globalization and expansion in the world markets, the sensitivity of investor's confidence has become a challenge especially in the wake of issues related to stock prices, earnings management (EM), the stability of income levels and corporate governance (CG) application. This study aims to explore the usefulness of four traits of corporate governance mechanism in constraining earnings management activities. By using five years' observations of 109 textile companies listed on Pakistan Stock Exchange (PSX) for the period 2013-2017. Traits comprising of board size, gender diversity, board experience and qualification of board member are analyzed using Ordinary Least Square (OLS). Results of the study submit that board experience; finance qualification and business qualification have a negative significant impact on EM thus contends that experienced board members having business and finance qualification discourage earnings manipulation. While, positive and significant impact of board size on earnings management is an indication of loss of control due to its large size. Moreover, gender diversity and chartered accountancy are found irrelevant to EM in our case.
\end{abstract}

Keywords: Corporate Governance; Earnings Management.

\section{Introduction}

Accounting manipulation by Enron, WorldCom, and Merck in a developed country like the United States made the investors shaky in their investment decisions. To protect their investment interest, investors have solid demand for an effective and efficient corporate governance system (Philip, 2011). The corporate governance system contains an extensive choice of policies and institutions, that include standards of accounting, rulesconcerning financial reporting, reward, size and structure of 
company board(Bajra \& Cadez, 2018).Due to globalization and expansion in the world markets, investor faces certain issues such as stock prices, earnings management, smooth level of income and corporate governance. These stock prices, book value, cash flow, earning management and corporate governance can disturb the financial statements (Khalil \& Mazraeh, 2016). Financial statements contain details about business functioning, business performance and state of business. The motive of financial statements is to give reliability and relevance. According to Financial Accounting Standard Board (FASB), reliability means the information which are given in the statements should be free of errors and fraud while, the relevance means that the correct information which has the capacity to make difference in decision and to help user to forecast the outcomes(Sholihah, 2013).Due to the above reason it is expected that the earning which they are showing in the income statement may be different from the actual value, and due to this the "earnings management" comes into play (Nuryaman, 2012).

CGhasa key role in reducing EM and with the decrease of earnings management investor risk also decreases when they are estimating the value of a firm using income. Thus, with the increase in corporate governance, value relevance also increase (Steven Balsam, 2003).High-quality regulatory environment improves the quality of firm information.e.g, a strong GC (investor protection) environment reduces earning management (Luez et al, 2005) and also improves value relevance of accounting data(Ali \& Hwang, 2000).From the last decade, corporate governance gained importance in the sphere of research in Pakistan. According to (Cheema, 2003) with the help of strong corporate governance system, Pakistan will be acharm for foreign direct investment and generate saving through capital if the CG system is in line with the objective of raising external equity capital through capital markets. Organizations started the adopation the quality rules and regulation to offer quality of financial information to their stakeholders. As,La Porta, Lopez-De-Silanes (1997) reported that a strong investor protection system regulates the capital marketsand also helpsto understand and improve the quality of firm financial information. Similarly, Bartov (2001)reported that robustinvestor protection system helps toenhance the standard of financial informationwith timely disclosure which helpsin reducedearinings management practices. The results of a study conducted in Pakistan proved thata solid surveillance system reduces earnings management and helps to develop the trust of investors' on the capital markets eventually leading to economic prosperity(Tahir, Ihtesham, \& Adnan, 2018).

Investors rely on disclosure of financial statements and firm financial information therein as reported by firms. Managers may, either to deceive stakeholders or to hide private benefits of control, alter the reported earnings(Tahir et al., 2018). As reported by Ghouma, (2018), an opportunistic manager may opt for altering the statements due to many reasons. In order to restrain opportunistic managers, accounting and standards setters have started revising these accounting standards to restrain such practices. Prior literature reports that a manager's discretion can also be controlled through regulatory environment such as strong investor protection. For example, 
Luez, (2003) and Gul et al., (2010) reported that countries and firms with strong CG leads to low earnings management in countries with more developed markets. This study is an attempt to examine whether firms in Pakistan are engage in earnings management from a developing market perspective. Moreover, this study is based on the prior literature premise that a strong CG and CG system results in less manipulation of earnings. Thus, this study also empirically tests this theory and perspective in a country, which is reported as a Common Law Country, should behave as a strong CG environment and developed capital market. This is a conformational study to fill the gap that exists among the results of different studies conducted in Pakistan.As studies conducted in Pakistan have resulted in non-identical outcomes e.g. (Zulfiqar, 2009) argues that the excellence of CG has a positive effect on earnings management in Pakistani corporate culture. While, Tahir et al., (2018) proved that a solid check and balance system reduces earning management and helps to develop the trust of investors 'on the capital markets. Thus, this study attempts to evaluate the application of various facets of $\mathrm{CG}$ in the reduction of the problem of earning management.

\section{Literature Review}

Managers play with the financial disclosure of the company for the sack of their own benefits to give good information to the market. This information performs an important role in the investments of investors. The information is reliable when it has a high-value relevance and this high-value relevant information can be given by a strong corporate governance system(Shan, 2015).

\section{Concept of Corporate Governance}

CG system can be explained as the process to control and monitor the works of company executive in such a way to ensure the interest of investor and shareholders (Parkinson, 1994).The corporate governance ensures the return of principal invested amount along with returns which gives confidence to the investor. The main work of theCG system is to focus on senior management with the principle of truthfulness, accountability and transparency (Cadbury, 1992). According to the findings of a recent study conducted in China on value relevance, earnings management and corporate governance, the value relevance is lower for those companies who are involved in EM while value relevance is high for those companies who are not involved in EM. A prior study examined the correspondence between C.G system and its impact on earning management. They draw the conclusion that the independent audit community and when the executives do not have any link with other companies can reduce the earnings management. For increased control on earnings management there must be a separation among the chairman, the chief executive officer and the manager as a membership to nominating (Kouki, Elkhaldi, Atri, \& Souid, 2011).In contrast the results of a study conducted in Pakistan (Zulfiqar, 2009), reveals that there is a constructivealliance between the worth of corporate governance and earnings management in Pakistani corporate culture.

In the current study, the following measures are used for CG: 


\section{Gender diversity (GD)}

In USA researchers have examined whether the gender of board members affect board performance. With the additional view-point female board member can increase the value of shareholder, but the impact may be negative if the appointment of female members is made because of social pressure for gender equality (Upadhyaya \& Puthenpurackal, 2010). The selection of GD as a measure of CG is made on the basis of Code of Corporate Governance Regulation (Pakistan, 2017), according to this amended regulation there must be at least one female director on BoDs. $\mathrm{D}_{1}$ dummy is used for GD.

\section{Qualification of the Board of Director:}

According to the Code of Corporate Governance Regulation amended in 2017, at least one committee member must be financial literate, which means that the person should be either a member of a recognized body of professional accountants or shall have a post-graduate degree in finance from HEC recognized institution. In the current study CAdumy represents certified Chartered Accountant, Fdumy represents degree in financial management and Bdumy is used for degree in business administration.

\section{Board Experience:}

The past literature describes that, the sequel of diversified experience on firm's performance has gained huge attention. The researchers tried to find the existence of top management biasness in policy formulation which shows their functional background, that in turn affects firm's performance (Laszlo Tihanyi, Alan E. Ellstrand, 2000; Barker \& Mueller, 2002; Tarus \& Aime, 2014).

Hambrick \& Mason (1984) shared that the previous studies on top management and $\mathrm{CEO}$ has verified that top managers having ample experience and knowledge in a particular field of functionality attains exceptional skills and capabilities in that field of strategic value to the organization. Board member having experience in the same area will think and act in a particular narrow way while, members having diversified experience will see the picture in a broader spectrum (Hambrick, \& Mason, 1984).

\section{Board Size:}

According to past studies bigger boards are harmful to the success of board. Lipton \& Lorsch (1992) claimed that bigger boards have a possibility to become non-functional because with the increase in board size, directors avoid criticizing the policies of top management. Moreover, due to the larger board productivity also suffers because of weak coordination, delayed decision making and risk aversion. (Yermack, 1996) found empirically that, firm value has inverse connection with board size (BS) in a sample of large US firms. According to the study of Vafeas (2010) larger board size has a positive relationship to shareholder value. However, the study of PuchetaMartínez (2015) explained that there is a particular limit of board size which is useful for performance improvement and above that limit value decreases with the addition of board members. Identical results were obtained by Hillman (2011) who explained 
that larger board size has the advantage of close supervision and guidance but has difficulties in governance, coordination and decision making.

\section{Earnings Management}

The present era companies believe in the theory of separate management, which means that ownership and the management rest in different hands. The managers will work on behalf of the shareholder and will work for the value of shareholders (to increase value and profit). The owners will provide some incentives based on the performance of the managers. Due to this, the conflict of interest arises. The managers labor for self-interest and play with the earnings of the company in order to get high rewards (Namazi, Bayazidi, \& Jabbarzadeh, 2011). For the attainment of financial benefits firms do not show their actual financial image, similarly the management also want to hide their personal advantage of control and the process is known as EM (Tahir et al., 2018). EM can be defined as setting freedom to accounting numbers and figures and there should be no restriction in this area (Watts \& Zimmerman, 1990). Healy \& Wahlen (1991) defined EM as a managerial technique of accounting entries to manipulate financial report either to misguide stakeholders about the firm's performance or to gain the advantage of a contractual outcome that dependents on accounting figures. A group of researchers in Pakistan (Tahir et al., 2018) examined the impact of CG on EM and found a negative relation between CG and EM. According to the study investor's confidence on the Capital Markets belongs to a strong monitoring system.

\section{Corporate Governance and Earnings Management}

Among the financial statements earnings report or the income report is the vital one and due to its huge importance, this report must have all the necessary information and should be consisted with reliability and value relevance factor. Investors like shareholders, debt holder, and any other stakeholders see the reliability of the information especially in the income statement, as this is a tool that describes the firm performance. To make investment decision investor look to the stock market and information for them is the financial report. However, as an alternative when the corporate governance system is of value such as (investor protection, independent board, auditor etc.) can improve the reliability of the information which is present in financial statements. The improved corporate governance system and the value of disclosure lead the investor to best economics decision. The previous study revealed a positive alliance between corporate governance and value of earning(Nuryaman, 2013). According to Bae, K.H.Ghoul (2017) the managers not only increase their incentives with different projects but also affect the revenue of shareholders while good CG not only enlarge the expectation of that managers to put in the net current value projects but also reduce the power of control which is given to the managers by shareholder and creditors. Best corporate governance can increase the quality of earnings and restrict management opportunistic behavior. Further, it helps the investor to take the best possible decision which is of economic value and can bring some 
return of it. That's why corporate governance system decreases the earnings management and increases reliability.

\section{Control Variables}

\section{Firm Size}

The firm size (FS) is a measure as Market Capitalization and depends on the nature of the company. The old measurement was the market value and the firm value in the market but that is not an accurate measurement. Therefore, the market capitalization is the best option to measure the firm size. Earlier studies i.e. (Sharma, Anurag, Kesner, $\&$ F, 1996) and (Mitchell, 1994) greatly measure the effect of size on the overall industry survival and disagreement in the performance of operations.

\section{Leverage}

Debts require predetermined commitments on firms that are irrelevant to the value of sales. As declines signify a stage of falling turnover in most cases, the companies advertising non-requirement objects can deal with a huge limitation on receipts and sales. Accordingly, debt can enforce a major danger on the company because of the linked financial suffering (Myers, 2001). At the same time as loan in an extension period offers chances for expansion and development, in collapse stage it can be complicated to retain (Myers, 2001).

With the increase of leverage, it is possible that the company finds it more complex to endure ages of diminishing sales, Moreover, a reduced amount of leveraged companies get better market share to their highly leveraged corresponding items.(Opler \& Titman, 1994). It was claimed by (Opler \& Titman, 1994) that economically stronger companies mostly use these periods of business decline to insistently overcome a better market share of their more at risk match companies by increased marketing and calculated pricing. What's more, they suggest that firms with high leverage and significant asset in examine and increase have a tendency to experience more and accept higher risk in financial system decline periods. As well Opler \& Titman, (1994) claim that leverage has a larger effect on a firm's survival and is more outstanding in more concentrated industries. 


\section{Conceptual Framework}

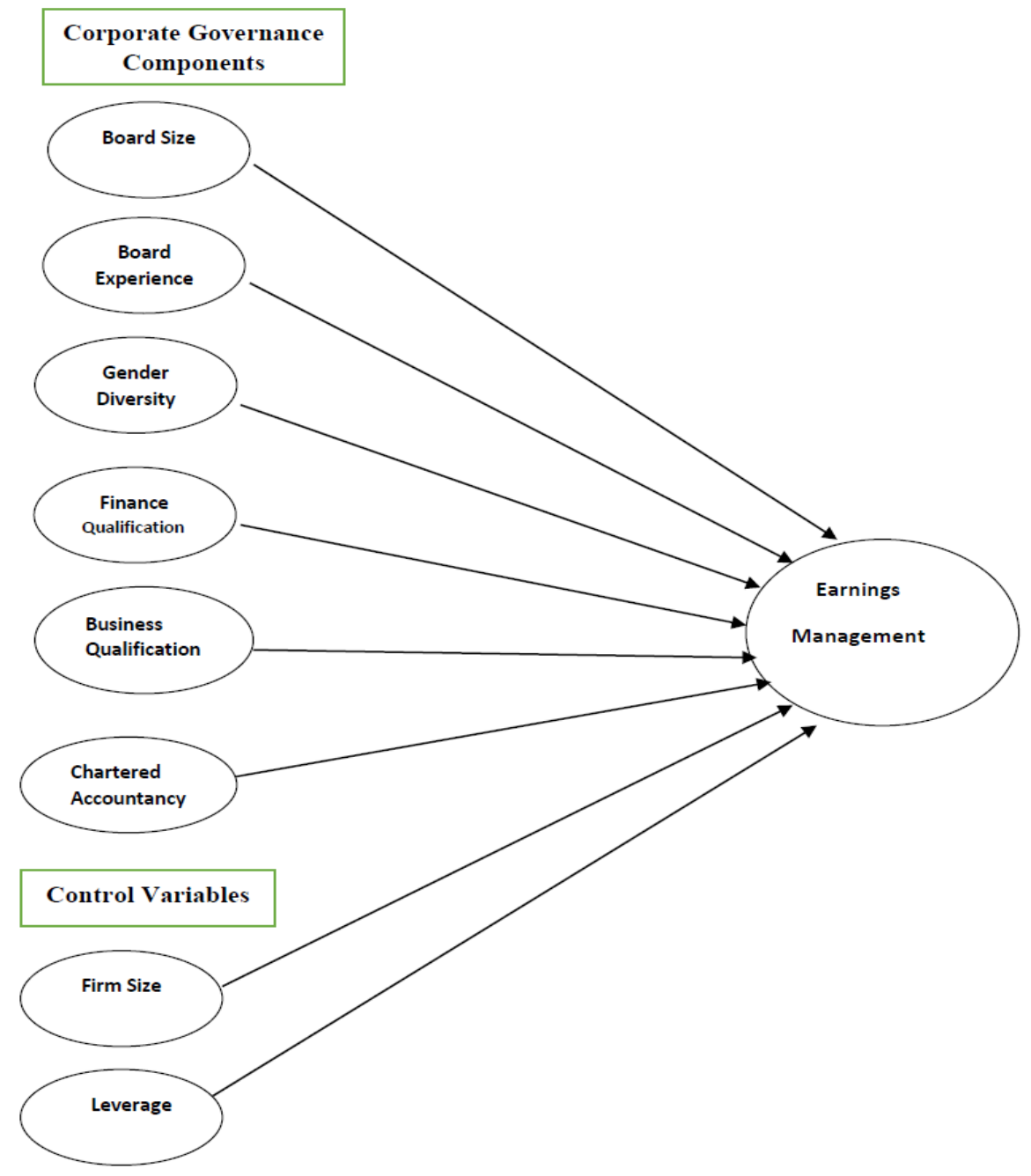

\section{Hypothesis of the study}

Based on the discussions \&literature of the study, following are the hypotheses.

H1: There is a significant negative impact of board size on earnings management.

H2: There is a significant negative impact of board experience on earnings management.

H3: There is a significant negative impact of financial qualification on earnings management. 
H4: There is a significant negative impact of business qualification on earnings management.

H5: There is a significant negative impact of professional qualification (chartered accountancy) on earnings management.

H6: There is a significant positive impact of board gender diversity on earnings management.

\section{Methodology \\ Population and Sampling:}

The population of the study is the Textile Industry of Pakistan. The total listed companies in Pakistan textile industry are 150 in which a sample of 109 companies has taken with the help of Raosoft sample size calculator ${ }_{1}$ and Saunder's probability sampling table with 95\% confidence level for the period of 2013-2017 (Saunders, Lewis, \& Thornhill, 2009). The sample is selected to ensure that its results can be generalized to the population as a whole. The reason for choosing this sector is that it has a major part in Pakistan GDP, due to which the data is easily available.

\section{Univariate Analysis:}

The univariate analysis consists of descriptive statistics which are mean, median, standard deviation, minimum, maximum, skewness and kurtosis etc. The study uses descriptive statistic for the dependent and independent variables. The dependent variable is earnings management and the independent variable is corporate governance (CG). Firm size and leverage are the controls variables.

\section{Multivariate Analysis}

In multivariate analyses correlation, and regression analyses are used.

Model: Earnings Management $=\beta_{0}+\beta_{1} \mathrm{BS}+\beta_{2} \mathrm{D}_{1}+\beta_{3} \mathrm{BE}+\beta_{4} \mathrm{BQ}+\beta_{5} \mathrm{FS}+\beta_{6} \mathrm{~L}+\varepsilon \mathrm{i}$ Measurement of Variables:

Table 01: The variables of interest are highlighted in below table.

\begin{tabular}{|c|c|c|c|}
\hline Variable & Acronyms & Measurement & Reference \\
\hline $\begin{array}{l}\text { Earnings } \\
\text { Management }\end{array}$ & EM & $\begin{array}{l}\mathrm{TA}=\Delta \mathrm{CA}-\Delta \mathrm{Cash}-\Delta \mathrm{CL}+\Delta \text { stdebt }- \\
\text { dep/At-1 }\end{array}$ & (Jones, 1991) \\
\hline Board Size & B.S & Number of board members & (Vafeas, 2010) \\
\hline $\begin{array}{l}\text { Gender } \\
\text { Diversity }\end{array}$ & G. D & $\begin{array}{l}\text { The ration between men and women in } \\
\text { board }\end{array}$ & $\begin{array}{l}\text { (Campbell \& } \\
\text { 2008) }\end{array}$ \\
\hline
\end{tabular}

${ }^{1}$ http://www.raosoft.com/samplesize.html 


\begin{tabular}{|c|c|c|c|}
\hline Experience & Exp. & $\begin{array}{l}\text { Technical experience (in years) of } \\
\text { members } \\
\text { on board }\end{array}$ & (Marimuthu, 2018) \\
\hline $\begin{array}{l}\text { Qualification } \\
\text { diversity }\end{array}$ & Qual. & $\begin{array}{l}\text { Ratio Total no. of board members with } \\
\text { technical qualification } \div \text { total board } \\
\text { members } \\
\text { (nualification diversitv terhnimal }\end{array}$ & (Marimuthu, 2018) \\
\hline Firm Size & FS & $\begin{array}{l}\text { Sales log or } \log \text { of total assets of the } \\
\text { organization }\end{array}$ & $\begin{array}{l}\text { (Khalil \& Mazraeh, } \\
\text { 2016) }\end{array}$ \\
\hline Leverage & $\mathrm{L}$ & Total debt $\div$ Total assets & $\begin{array}{l}\text { (Khalil \& Mazraeh, } \\
\text { 2016) }\end{array}$ \\
\hline
\end{tabular}

\section{Results and discussion}

\section{Descriptive statistics and Frequencies}

Descriptive statistics is the blend of different statistical procedures that explains the data with respect to different measures which describes diverse characteristics of the data such as the number of observations, mean, median, maximum, minimum and standard deviation. Correspondingly, frequencies show the number of incidences of a certain trait of an observation or the recurring of a number or the assessment of the percentage of a specific element against the total observations or data set. This condense data form gives us a global inkling of the data as it is the combination of different vita calculations.

Table 2: Descriptive Statistics

\begin{tabular}{|c|c|c|c|c|c|c|c|c|c|}
\hline & $\mathrm{N}$ & $\begin{array}{l}\text { Minimu } \\
\mathrm{m}\end{array}$ & $\begin{array}{l}\text { Maximu } \\
\mathrm{m}\end{array}$ & Mean & $\begin{array}{l}\text { Std. } \\
\text { Deviatio } \\
\mathrm{n}\end{array}$ & $\begin{array}{l}\quad \text { Ske } \\
\text { Statistics } \\
\text { S.E }\end{array}$ & ness & $\begin{array}{l}\text { Kurtosis } \\
\text { Statistics } \\
\text { S.E }\end{array}$ & \\
\hline EM & 544 & -22.983 & 12.735 & $\begin{array}{l}0.001 \\
04\end{array}$ & 1.503 & -5.346 & .105 & 124.34 & .210 \\
\hline $\mathrm{BS}$ & 544 & 7 & 11 & 7.42 & 0.782 & 2.361 & .105 & 6.544 & .209 \\
\hline LnL & 544 & -5.76 & 9.09 & $\begin{array}{l}0.770 \\
3\end{array}$ & 1.435 & 2.206 & .105 & 9.702 & .209 \\
\hline LnFS & 544 & 0.89 & 2.47 & $\begin{array}{l}2.019 \\
9\end{array}$ & 0.2405 & -1.398 & .105 & 3.616 & .209 \\
\hline Exp. & 544 & 6.429 & 37.643 & 18.09 & 5.67 & 0.602 & .105 & .621 & 209 \\
\hline Frequencies & & & & Yes & No & Yes\% & No\% & $\%$ & Cum \\
\hline FinD & 544 & 0 & 1 & 330 & 214 & 60.7 & 39.3 & 60.7 & 100 \\
\hline Bdumy & 544 & 0 & 1 & 319 & 225 & 58.6 & 41.4 & 58.6 & 100 \\
\hline Cadumy & 544 & 0 & 1 & 429 & 115 & 78.9 & 21.1 & 78.9 & 100 \\
\hline D1 & 544 & 0 & 1 & 294 & 250 & 54.0 & 46.0 & 54.0 & 100 \\
\hline
\end{tabular}


Table 3: Correlation Matrix

\begin{tabular}{|c|c|c|c|c|c|c|c|c|c|c|}
\hline & (1) & (2) & (3) & (4) & (5) & (6) & (7) & (8) & (9) & (10) \\
\hline (1) EM & 1 & & & & & & & & & \\
\hline (2) BS & .025 & 1 & & & & & & & & \\
\hline (3) $\mathrm{LnL}$ & $-.093^{*}$ & $.352^{* *}$ & 1 & & & & & & & \\
\hline (4) $\mathrm{LnFS}$ & .013 & $.196^{* *}$ & $-309^{* *}$ & 1 & & & & & & \\
\hline (5) Exp. & -.048 & .036 & $.221^{* *}$ & $.251^{*}$ & 1 & & & & & \\
\hline (6) FinD & $-.094^{*}$ & $.124^{* * *}$ & $-.087^{*}$ & $.119^{*}$ & $.265^{* *}$ & 1 & & & & \\
\hline (7) Bdumy & -.054 & $.172^{* *}$ & - & $.207^{*}$ & $.190^{* * *}$ & $.241^{* *}$ & 1 & & & \\
\hline (8) Cadumy & -.021 & $.242^{* *}$ & $\begin{array}{l}- \\
.161^{* * *}\end{array}$ & $.201^{*}$ & $.149^{* * *}$ & $.274^{* *}$ & $.114^{* *}$ & 1 & & \\
\hline (9) D1 & .002 & $\begin{array}{l}-176^{* *} \\
\end{array}$ & $.155^{* * *}$ & $.253^{*}$ & $230^{* * *}$ & -.063 & $.087^{*}$ & .019 & 1 & \\
\hline (10) Log EM & $.497^{* *}$ & -.094 & .018 & $\begin{array}{l}- \\
.175^{*}\end{array}$ & -.063 & -.015 & $-.026^{*}$ & -.094 & $.125^{*}$ & 1 \\
\hline
\end{tabular}

*. Correlation is significant at the 0.05 level (2-tailed).

**. Correlation is significant at the 0.01 level (2-tailed).

Reports the correlation of EM (Earning Management), BS (Board Size), LnL (Log of Leverage), and LnFS (Log of Finance Qualification) and the EXP (Experience), FinD (Finance Degree), Dummies B (Business) and Ca (Certified Accountancy) and D1 (Gender Diversity)

The statistical outcomes above witness that all the variables have a hundred percent correlation with itself; however, every individual variable has an unlike level of correlation with other variables.It is evident that there is a statistically negative association of Earnings Management with leverage at a correlation coefficient of 0.093 at $\alpha<0.05$. Similarly, Finance Qualification is negatively and significantly correlated with Earnings Management with a correlation coefficient of 0-.094 $\alpha<0.05$. Moreover, Log of EM is positively and significantly correlated with Earnings Management at the coefficient of $0.497 \alpha<0.01$. While Board Size, Firm Size, Board Experience, Business Qualification, CA Qualification and Gender Diversity is insignificant. 


\section{OLS estimation analysis}

Table 4: OLS estimation Linear regression

\begin{tabular}{|c|c|c|c|c|c|}
\hline EM & Coef. & St.Err & $\mathrm{t}$-value & $\mathrm{p}$-value & Sig. \\
\hline $\mathrm{BS}$ & 0.047 & 0.090 & 0.52 & 0.600 & \\
\hline Exp. & -0.057 & 0.067 & -0.85 & 0.393 & \\
\hline FinD & -0.220 & 0.133 & -1.65 & 0.099 & $*$ \\
\hline Bdumy & -0.103 & 0.130 & -0.79 & 0.431 & \\
\hline Cadumy & -0.033 & 0.156 & -0.21 & 0.832 & \\
\hline D1 & 0.060 & 0.129 & 0.46 & 0.644 & \\
\hline LagEM & 0.229 & 0.063 & 3.65 & 0.000 & $* * *$ \\
\hline $\mathrm{LnL}$ & -0.159 & 0.069 & -2.31 & 0.021 & $* *$ \\
\hline LnFS & 0.120 & 0.069 & 1.75 & 0.081 & $*$ \\
\hline Year Dummy1 & 0.000 & & . & . & \\
\hline Year Dummy2 & -0.423 & 0.189 & -2.24 & 0.026 & $* *$ \\
\hline Year Dummy3 & -0.149 & 0.188 & -0.79 & 0.429 & \\
\hline Year Dummy4 & -0.097 & 0.189 & -0.52 & 0.607 & \\
\hline Year Dummy5 & -0.042 & 0.190 & -0.22 & 0.826 & \\
\hline Constant & 0.225 & 0.158 & 1.42 & 0.157 & \\
\hline Mean dependent var & -0.022 & & SD dependent var & 1.4 & \\
\hline R-squared & 0.057 & & Number of obs & 538 & \\
\hline F-test & 2.428 & & Prob $>$ F & 0.0 & \\
\hline Akaike crit. (AIC) & 1886.604 & & Bayesian crit. (BIC) & 194 & 634 \\
\hline
\end{tabular}

Reports OLS estimation analysis pertaining EM (Earning Management), BS (Board Size), LnL (Log of Leverage), and LnFS (Log of Finance Qualification) and the EXP (Experience), FinD (Finance Degree), Bdumy(Business) and $\mathrm{Ca}$ (Certified Accountancy), D1 (Gender Diversity)

The results of table 4 suggest that finance dummy is negatively associated with earnings management at $\boldsymbol{\alpha}<\mathbf{0 . 1}$, Similarly, LnLeverage and Y. d2 also have a negative and significant relationship with earnings management at $\boldsymbol{\alpha}<0.5$ which means that an increase in finance qualification, leverage and $\mathrm{Y}$. $\mathrm{d} 2$ will reduce earnings management, while NFS and LagEM are positively associated with EM. However, the $\mathrm{p}$ values of board size, board experience, business dummy, CA dummy and gender diversity are great than $\boldsymbol{\alpha}<\mathbf{0 . 1}$ which shows that these are insignificant. F-value compares the overall fitness of the model to the relevant data. P-value of the F test signifies the fitness. Thus, if the relevant $\mathrm{p}$-value is less than the significance level then the selected sample data fits the regression model well. Therefore, in this case the $\mathrm{f}$-value of the above model is statistically significant ( $\mathrm{p}$-value $\leq 0.003$ ), thus it is concluded here that the model fits the data well. Adding to it is the adjusted R-squared 
which is $5.7 \%$, presenting that the above independent variables of CG have a very low effect on curtailing earning manipulation practices of the mangers.

\section{Breusch Pagan Heteroscedasticity test}

This test helps to check the $\mathrm{H}_{0}$ against the $\mathrm{H}_{1} . \mathrm{H}_{0}$ is homoscedasticity, which states "all the error variances are equal", and $\mathrm{H}_{1}$ tells us about heteroscedasticity "the error variances are a multiplicative function of one or more variables".

Table 5: Breusch Pagan test

Breusch--Pagan or Cook Weisberg test for heteroscedasticity

Ho: Constant variance

Variables. fitted values of Earnings Mgt

$\operatorname{chi} 2(8) \quad=527.67$

Prob $>$ chi $2=0.00$

The above table reflects that the probability value of the chi-square statistic is less than $5 \%$. Hence, $\mathrm{H}_{0}$ can be rejected at 0.05 level of significance, which suggests the presence of heteroscedasticity in the residuals. As a result of the heteroscedasticity OLS estimates are no longer BLUE (Best Linear Unbiased Estimator) as, shown in above table (table 4.2.4) and therefore, standard errors will be unreliable, which will further cause bias in test results and confidence intervals. In this study PanelCorrected Standard Error (PCSE) estimator is used for regression.

\section{Panel Corrected Standard Errors}

According to Bailey (2018) PCSE method shows coexistent association among units and unit- level heteroscedasticity makes a better level of inferences as compared to linear model.

Table 6: PraisWinsten regression PCSEs

\begin{tabular}{lllllll}
\hline Earningsmgt & Coef. & St. Err & t-value & p-value & Sig. & Hypotheses \\
\hline BS & 0.091 & 0.055 & 1.67 & 0.096 & $*$ & Reject \\
Exp. & -0.062 & 0.034 & -1.86 & 0.062 & $*$ & Accept \\
FinD & -0.388 & 0.144 & -2.70 & 0.007 & $* * *$ & Accept \\
Bdumy & -0.089 & 0.042 & -2.09 & 0.036 & $* *$ & Accept \\
Cadumy & -0.046 & 0.086 & -0.53 & 0.597 & & No effect \\
D1 & 0.133 & 0.090 & 1.48 & 0.139 & & No effect \\
LagEM & 0.349 & 0.124 & 2.82 & 0.005 & $* * *$ & \\
NLeverag & -0.245 & 0.077 & -3.17 & 0.002 & $* * *$ & \\
NFirmSize & 0.201 & 0.078 & 2.59 & 0.010 & $* *$ & \\
Year Dummy1 & 0.000 &. & - &. & & \\
Year Dummy2 & -0.424 & 0.078 & -5.42 & 0.000 & $* * *$ &
\end{tabular}




$\begin{array}{llllll}\text { Year Dummy3 } & -0.188 & 0.065 & -2.91 & 0.004 & * * * \\ \text { Year Dummy4 } & -0.193 & 0.066 & -2.94 & 0.003 & * * * \\ \text { Year Dummy5 } & -0.055 & 0.071 & -0.78 & 0.437 & \\ \text { Constant } & 0.244 & 0.054 & 4.54 & 0.000 & * * * \\ & & & & & \end{array}$

\begin{tabular}{llll}
\hline Mean dependent var & -0.022 & SD dependent var & 1.40 \\
& & & 3 \\
R-squared & 0.125 & Number of obs & 538. \\
& & & 000 \\
Chi-square & 96.774 & Prob> chi2 & 0.00 \\
& & & 0
\end{tabular}

$* * * \mathrm{p}<0.01, * * \mathrm{p}<0.05, * \mathrm{p}<0.1$

The empirical outcomes of model 6 show that board experience, finance dummy, business dummy, leverage, Year Dummy1-4 have a negative and significant relationship with the earnings management while B. Size, LagEM and Firm Size have a positive and significant relationship with the dependent variable. Similarly, CAdumy, D1 (gender diversity) and Y. d5 are insignificant. The value of $\mathrm{R}^{2}$ is 0.125 which shows that all explanatory variables describe $12.5 \%$ variation in the dependent variable.

\section{Conclusion}

Results of the study submit that board experience; finance qualification and business qualification are found to have a negative and significant impact on earnings management thus contends that experienced board members and having business and finance qualification discourage earnings manipulation. Salterio (2001) proposed that finance-related professionals have expertise regarding mitigation of the risk of earning management. Peasnell et al. (2000) focuses on board diversity while Cornett and Marcus, (2008) suggested that outside directors bring experience thus results in reduction of EM. While, positive and significant impact of board size and firm size on EM is an indication of loss of control due to its large size (Zulfiqar, 2009). Abed, AlAttar \& Suwaidan (2012) found a significant role of board size on EM, While Chekili (2012) found the same positive relationship while, Soliman \& Ragab (2013) found an inverse perspective in this regard. Moreover, gender diversity is found irrelevant to EM. Researchers like Rose (2007) found no significant relationship, while Bunjamin \& Hiswara (2012) found a positive relationship in this regard. Gender diversity and chartered accountancy are statistically meaningless on EM, Reguera-Alvarado (2017) also obtained the same results and found that there is no impact of board diversity on firm performance. 


\section{References}

Abed, S., Al-Attar, A., \& Suwaidan, M. (2012). Corporate Governance and Earnings Management: Jordanian Evidence. International Business Research, 5(1), 216225.

Aime, T. \&. (2014). Board demographic diversity, firm performance and strategic change A test of moderation. Management Research Review, 37(12), 1110.

Ali, \& Hwang. (2000). Country-specific factors related to financial reporting and the value relevance of accounting data. Journal of Accounting Research, 38(1), 121.

Bae, K.H.Ghoul, G. (2017). Does Corporate Social Responsibilities Reduce the Costs of High Leverage? Evidance from Capital Structure and Product Market Interactions. Journal of Banking and Finance, Forthcoming.

Bailey, D, K. (2018). Package “pcse.” American Political Science Review, 87, 945948.

Bajra, U., \& Cadez, S. (2018). The Impact of Corporate Governance Quality on Earnings Management: Evidence from European Companies Cross-listed in the US. Australian Accounting Review, 28(2), 152-166. https://doi.org/10.1111/auar.12176

Bartov, E., Goldberg, S. R., \& Kim, M. (2001). The Valuation-relevance of Earnings and Cash Flows. An International Perspective. Journal of International Financial Management and Accounting, 12(2), 103-132.

Bunjamin, Hiswara, T. and H. S. In Guide to anti-corruption regulation in Asia (2012). Retrieved from hongkong: www.herbertsmith.com

Cadbury. (1992). Committee on the Financial Aspects of Corporate Governance Report with Code of Best Practice. London: Gee Publishing.

Campbell, K., \& M1, A. (2008). Gender Diversity in the Boardroom and Firm Financial Performance. Journal of Business Ethics, 83, 435-451. https://doi.org/10.1007/s10551-007-9630-y

Cheema. (2003). Corporate governance in Pakistan. The Journal, NIPA, Karachi, 8, $7-19$.

Chekili. (2012). Impact of some governance mechanisms on earnings management: An empirical validation within the Tunisian market. Journal of Business Studies, 3(3), 95-104.

Cornett, Marcus, \& T. (2008). The impact of earnings management. Journal of Financial Economics, 87(2), 357-373. 
Ghouma, H. \& H. (2018). Corporate governance and cost of debt financing: Empirical evidence from Canada. Quarterly Review of Economics and Finance, 67, 138148. https://doi.org/10.1016/j.qref.2017.06.004

Hambrick, D. C., \& Mason, P. A. (1984). The organization as a reflection of its top managers. Academy of Management Review, 9(2), 193-206.

Healy, \& P. M., \& Wahlen, J. M. (1991). A review of the earnings management literature and its implications for standard setting. Accounting Horizons, 13(4), 365-383.

Hillman, A.J., Shropshire, C., Certo, S.T., Dalton, D.R., D. (2011). What I like about you: A multilevel study of shareholder discontent with director monitoring. Organization Science, 22(3), 675-687.

Jones, J. J. (1991). Earnings Management During Import Relief Investigations. Journal of Accounting Research, 29(2), 193-228. https://doi.org/10.2307/2491047

Khalil, E., \& Mazraeh, Y. A. (2016). An Investigation into the relationship between Value Relevance, Earnings Management and Corporate Governance of listed companies in Tehran Stock Exchange. International Journal of Humanities and Cultural Studies ISSN 2356-5926, 3(1), 586-598.

Kouki, M., Elkhaldi, A., Atri, H., \& Souid, S. (2011). Does corporate governance constrain earnings management? Evidence from U.S. firms. European Journal of Economics, Finance and Administrative Sciences, (35), 58-71.

Laszlo Tihanyi, Alan E. Ellstrand, C. M. D. (2000). Composition of the Top Management Team and Firm International Diversification. Journal of Management, 26(6), 1157-1177.

Lipton \& Lorsch. (1992). A modest proposal for improved corporate governance. Business Lawyer, 48, 59-77.

Luez. (2003). Earnings management and investor protection: An international comparison. Journal of Financial Economics, 69, 505-527.

Marimuthu, R. H. \& M. (2018). Contextualizing comprehensive board diversity and firm financial performance: Integrating market, management and shareholder 's perspective. Journal of Management \& Organization, 24(5), 634-678.

Mitchell. (1994). The dynamics of evolving markets: The effects of business sales and age on dissolutions and divestitures. Administrative Science Quarterly, 39, 575602.

Myers, S. C. (2001). Capital Structure. The Journal of Economic Perspectives, 15(2), 81-102. 
Namazi, Bayazidi, \& Jabbarzadeh. (2011). Determining the relationship between auditing quality and earnings management for listed companies in the Tehran Security Exchange. Accounting Research, 3(6), 4-21.

Nuryaman. (2012). The Influence of Corporate Governance Practices on the Company's Financial Performance. Journal of Global Business and Economics, $5(1), 1-17$.

Opler, T. I. M. C., \& Titman, S. (1994). Financial Distress and Corporate Performance. The Journal of Finance, XLIX(3), 1015-1040.

Pakistan, G. of P.-S. and E. C. of. Listed Companies (Code of Corporate Governance) Regulations, 2017, 704 § (2017).

Parkinson. (1994). Corporate Power and Responsibility. Theory of Company Law, Clarendon Press, Oxford, UK.

Peasnell, P. F. P. and S. Y. (2000). Board monitoring and earnings management: Do outside directors influence abnormal accruals? JEL Classification: M41, G34.

Philip, T. (2011). Corporate governance mechanisms and earnings management in transitional countries - Evidence from Chinese listed firms. Https://Trove.Nla.Gov.Au/Version/172607554, (May), 1-220.

Pucheta-Martínez. (2015). El papel del Consejo de Administración en la creación de valor en la empresa. Revista de Contabilidad - Spanish Accounting Review, $18(2), 148-161$.

Puthenpurackal, \& U. (2010). Board gender diversity and firm performance: The impact of information environment.

Reguera-Alvarado, N., de F. \& L. (2017). Does board gender diversity influence financial performance? Evidance from Spain. Journal of Business Ethics, 141(2), 337-350.

Rose, C. (2007). Does female board representation influence firm performance. $A n$ International Review, 15(2), 404-413.

Salterio, F. T. D. and S. E. (2001). 10) The Effects of Corporate Governance Experience and Financial-Reporting and Audit Knowledge on Audit Committee Members' Judgments. A Journal of Practice \& Theory, 20, 2.

Saunders, M., Lewis, P., \& Thornhill, A. (2009). Research Methods for Business Students (5th ed.). Retrieved from https://doi.org/10.1017/CBO9781107415324.004

Shan, Y. G. (2015). Value relevance, earnings management and corporate governance in China. Emerging Markets Review, 23, 186-207.

Sharma, Anurag, Kesner, \& F, I. (1996). Diversifying Entry: Some Ex Ante 
Explanations for Postentry Survival and Growth. Academy of Management Journal, 39(3), 635-677.

Shleifer \& Vishny, La Porta, R., \& Lopez-De-Silanes R.W. (1997). Legal determinants of external Finance. The Journal of Finance, LII(3), 1131-1150.

Sholihah. (2013). The effect of Earnings Management on the Value Relevance of Earnings and Book Value. Ilmaih Mahasiswa FEB, 01(02), 15.

Soliman, M.M., \& Ragab, A. A. (2013). Board of director's attributes and earning management: Evidence from Egypt. In Proceedings of 6th International Business and Social Sciences Research Conference. Dubai, UAE.

Steven Balsam. (2003). Auditor Industry Specialization and Earnings Quality. A Journal of Practice \& Theory, 22(2), 71-97.

Tahir, Ihtesham, \& Adnan. (2018). The Impact of Corporate Governance on Earnings Management: Empirical Evidence from Pakistan. Journal of Research in Social Sciences, 6(2), 256 - 271.

Vafeas, S. L. Æ. N. (2010). The relation between board size and firm performance in firms with a history of poor operating performance. Springer Science + Business Media, LLC. 2009 Abstract, 14, 61-85. https://doi.org/10.1007/s10997-0099091-z

Watts, R. L., \& Zimmerman, J. L. (1990). Accounting Year Theory : Ten Perspective. The Accounting Review, 65(1), 131-156.

Yermack, D. (1996). Higher market valuation of companies with a small board of directors. Journal of Financial Economics, 40, 185-212.

Zulfiqar, S. A. (2009). Corporate Governance and Earnings Management an Empirical Evidence Form Pakistani Listed Companies. European Journal of Scientific Research ISSN 1450-216X Vol.26 No.4(2009), Pp.624-638, 26(4), 624-638. 